\title{
The Dynamic Mechanism of Logistics Networking Industry in Jing-Jin-Ji Region of China in the Context of"'Internet +"
}

\author{
Bo Shu ${ }^{1,2,3}$,Shan $\mathrm{Lu}^{1,2}$ and Haiju $\mathrm{Hu}^{2 *}$ \\ ${ }^{1}$ Management Innovation Research Center of Yanshan University about \\ Coordinated Development of Jing-Jin-Ji, Qinhuangdao, 066004, \\ Qinhuangdao 066004, P.R. China \\ ${ }^{2}$ Economics and Management School, Yanshan University, \\ Qinhuangdao 066004, P.R. China \\ ${ }^{3}$ Institute of Modern Tourism Industry and Organizational Development, \\ Yanshan University
}

\begin{abstract}
With the development of cloud computing, big data, Internet of things, the traditional logistics industry integration of the Internet. It gave birth to a variety of business models and Shared prosperity. It has discovered the dynamic factors of logistics industry in JingJin-Ji region (Beijing, Tianjin and Hebei region) were related to the regional network, industry integration and business innovation, etc. This article, based on the investigation of "the networked logistics industry" in Beijing, Tianjin, Hebei, influence elements of logistics industry,established the model of combination of the dynamics.The model reflected the network in the process of logistics industry, which including four dimensions :the logistics industry benefit, scale of logistics, the logistics demand and logistics network resources, to simulate the trend of the logistics industry network. In addition, It observed the dynamic effect of the four-dimensional one completely changed. It has been found that the influence of scale of logistics efficiency and logistics more network logistics industry in Jing-Jin-Ji. But it is not obvious, the influence of the network resources, the logistics demand of network logistics industry in Jing-Jin-Ji area.
\end{abstract}

Keywords: logistics industry, dynamic mechanism of networking, “ Internet + ”, Jing-Jin-Ji region

\section{Introduction}

China's economy evolution has tend to a form of more advanced in pattern ,more complex in division of labor, more reasonable in structure, the development of regional logistics industry presented new normal pattern, It was the main objective to realize economic growth healthily in the new development environment. The logistics circle of Jing-Jin-Ji, a trade gathering area of growing fast, was one of the most dynamic regions of China's economic circles, besides Pearl River Delta, Yangtze River Delta. Logistics industry in Jing-Jin-Ji faced an opportunity of regional economic integration, also assumed a responsibility for promoting economic "second growth", Intensive management and grid management of the logistics industry, as the main path, promoted the healthy development of the logistics. At the macro environment of the logistics industry coordinated development in Jing-Jin-Ji, on one hand, aggregating existing types of logistics information capital, constituting a system of interoperable and share platform ;on the other hand, improving the mechanism of data docking, and reinforcing the interoperability of cross-category information, which provided robust propulsion to

${ }^{*}$ Corresponding Author 
logistics system and economic development of Jing-Jin-Ji, has become the focus of research in economic integration development.

Researches on the logistics network mainly in two directions: Logistics physical network and logistics information network. H. Gleissner, J.C. Femerling (2015) pointed out logistics information network and logistics network were the key of logistics system designing. The study of logistics network mainly focused on the distribution of traffic network study [1-2]; Sundar (2002)researched on Ghana and Nigeria , provided a evolution model about transportation network [3]; Tomoya. Moriy (2001)developed a business model to describe the development of transport routes and a five-stage hierarchy of urban growth in North America [4]; Ezzeddine Fatnassi (2015) investigated how they could share a rapid transit network and used the available transportation capacity within a city more efficiently in an interconnected way [5];Adil Baykaso glu, Kemal Subulan ( 2015) presented fuzzy efficient solutions and analysis for a fully fuzzy reverse logistics network designing problem with fuzzy decision variables. The computational results had shown that more reliable and necessarily precise solutions can be generated by the proposed method for a risk-averse decisionmaker[6];Feng (2012)proposed a regional logistics network based on hub-and-spoke network model to strengthen the promotion of the regional logistics towards the regional economic development [7]; Bruzzone(2011) etal focused on the development of a new simulator of micro activities in a logistics node, which could extend the capabilities of a logistics node over its current capabilities effectively[8];Tang et. al., (2004) discussed the integrated decisions for logistics network in a global manufacturing system based on heuristic algorithms[9]; Schönsleben(2000)proposed partnership strategies towards logistics networks, and revealed that the duration and intensity of cooperation within a logistics network would cause different Consequences[10];Wang and Feng (2011)established a regional logistics node layout optimization model, based on weighted Voronoi diagram and the discrete generation algorithm. They provided a new research idea to the logistics node relationship study [11];A logistics network nodes planning and development strategy was described by Cao, and a logistics network in Henan province was taken as an example. In the work, a four-layer logistics network was designed[12].Wei Deng Moulay Hicham Hakam, Solvang (2012) cited the case studies in a sparsely populated area in northern Norway and analyzed that economic and environmental sustainability of the logistics network can be achieved through a combination of reverse logistics network and advanced logistics management [13] ; Maria et. al.,(2002)used Latin America as a study case, studied the relationship between transport networks and regional planning basis for social-economic development, pointed out that the integration of Latin America's transportation network was conducive to regional economic development [14]; TageSkjot-Larsen et. al.,(2003) from Denmark and Sweden, used Oresund Bridge as a case study to analyze the impact of the bridge on the efficiency of transport corridors and regional networks, indicated action of regional economic joint development can improve transport infrastructure to facilitate logistics and operational efficiency [15]; Tuzkaya(2011)studied the Northeast Ohio logistics network, as well as organizational network carriers, shippers and the public sector were the experience of the overall development of regional logistics industry [16];PerryA, Trunic(2003) analyzed the Atlanta was responsible for the construction of urban logistics planning by founding Logistics Task Force who paid attention to urban transportation, logistics nodes and highway construction so as to promote regional logistics development [17]; DeMarco (2007)exploited the northwest region of Italy as the research object, built the system dynamics model to optimize logistics and transportation network[18];Zou Chenguang based on the internet of things, designed the framework of the regional logistics intelligence information platform, and analyzed the positive influence of the platform on regional logistics and regional economic development[19];Gulcin Buyukozkan, Orhan Feyzioglu, Erdal Nebol (2007) intended to provide decision support for the company by assessing of electronic logistics partner 
carefully, made a " multi-criteria decision making (MCDM)" approach to assess effectively the electronic logistics network based on strategic alliances[20]; Alexander Smirnov (2008) proposed Internet technology was a method ontology and environmental management information sharing [21]; Xiaopeng Li (2013) studied the integrated logistics networks, determined the optimal location of the supplier and in an uncertain environment, inventory management strategy, proposed a mathematical model to determine the optimal minimize the expected total cost of the system network design [22]; YiPeng, HongChen (2013) proposed a system dynamics model, simulated and analyzed the association between prediction of road network and latency information by disrupting the behavior of Supply chain relationships [23]; GuiPing Du et. al., (2003) proposed a system dynamics modeling of regional logistics network system structures by analyzing the rule of the formation and evolution process. The relationship between the constituent elements were analyzed [24]; From the perspective of industrial cluster theory, Haifeng et. al.,(2010) studied the mechanism of elements interaction between logistical activities in the theory of Industry Cluster [25]; From the perspective of the theory of dissipative structure system, ZhaoLei Li et. al.,(2010) studied the evolution of the regional logistics system and built a dissipative structure evolution mode,Explored the driving factors of system coordinated development, It found that the construction of regional logistics network were related to the regional economy,regional transportation and regional level of consumption, etc[26].

In recent years, the most well-known Internet, as digital network technology, provided logistics services in the manner of computer interconnection network transparently [27]. With the mature of business model of cloud computing, big data, things networking and other internet technologies, the traditional manufacturing integrated logistics industry, giving birth to a variety of commercial paradigm, presenting prosperity of shared economy. The new environment of "Internet+", fostered new consumer groups and generated significant economic and social values [28-29].Networking of Logistics industry was a firm support on cross-border e-commerce of Internet-based logistics [3032].

\section{The Definition of Regional Logistics Industry Networking}

Rochdi Sarraj, Eric Ballot, Shenle Pan, who believed that the logistics networks which currently being developed are intertwined but heterogeneous with supply chain networks, proposed a concept: new logistics network is physical logistics network designed to provide interconnection services. And gave an inherent potential logistics network interconnection instructions [33].The logistics networks, from the perspective of supply chain system to understand, were entangled flows which conveyed the complex friendships and trees in geographical between the suppliers and customers[34]. However, new logistics networks were inseparable with information, business and financial flows which delivered over the internet. Networking of logistics industry, which depends on "Internet+" environment, was a process being formed to new business model connected with the logistics networked.

In this paper, the definition of regional logistics industry networks was: a platform of sharing networks, which were built by logistics enterprises through Internet access about e-commerce, provided interactive services along with the flows of cross-border business. Obviously, networking of logistics industry was established at the collaborative development of regional logistics industry and the concept of "Internet +". It was a dynamic process the logistics industry setting up Internet platform and distribution network business, driven by the parameters which were the power of logistics industry evolved. Among the variables, which affected and controlled the networking were driving elements, which were affected by others 
called the result elements, which between control variables and result variables were mediating elements. The driving elements played an important role in networking of logistics industry. So understanding the dynamical mechanism was not only the key to find driving factors to control the direction of regional logistics industry development, but also was the main way to regulate the balance of the development of regional logistics industry .

\section{Networking of Logistics Industry in Jing-Jin-Ji}

This paper collected the indicators about the development of logistics companies in Beijing, Tianjin and Hebei, surveyed 300 companies in Beijing, Tianjin, and Hebei as samples (each 100) on the internet construction of logistics companies through the way of web-based survey. Those Established a mature self-business network were regarded as companies had been networked. Those had no their own network of enterprises were deemed as companies not interconnected, some of companies had added the websites of Ganji and 58 Tong Cheng were not within the scope of the networked companies, but those added third-party network and published their e-commerce products through the platform, for example: logistics China logistics network, China supplies net, the division business network etc., were deemed to the enterprises had networked. Table 1 showed the result of the survey on Beijing, Tianjin and Hebei, which displayed the networked rates of logistics industry from 2005 to 2014.

Table 1. Networked Rates of Logistics Industry in Jing-Jin-Ji Region

\begin{tabular}{l|l}
\hline Year & Networked Rate \\
\hline 2005 & 0.140 \\
\hline 2006 & 0.200 \\
\hline 2007 & 0.220 \\
\hline 2008 & 0.250 \\
\hline 2009 & 0.300 \\
\hline 2010 & 0.327 \\
\hline 2011 & 0.360 \\
\hline 2012 & 0.403 \\
\hline 2013 & 0.450 \\
\hline 2014 & 0.533 \\
\hline
\end{tabular}

\section{The Dynamic Model of Logistics Industry Networking in Jing-Jin-Ji Region}

\subsection{Analysis of the Causal Relationship on Regional Logistics Industry Networking}

Regional logistics network was a complex connective tissue which had close relationship with regional economy and regional transport. The construction of regional logistics industry not only connected with regional logistics network, but also closely linked with the regional economy, regional transport and levels of regional consumption. Evidently, the indexes of networking of regional logistics industry were complex and diverse. Among the research on regional logistics development, there were many representatives which established index system, such as: Li Zhao (2012) selected the indexes of cargo quantity, passenger traffic quantity, the total transportation distance, employment quantity on transportation and warehousing industries to reflect the level of 
development of logistics[35]; Poncet S (2003) pointed out that the promotion of the level of regional economic development would bring further growth in demands for logistics, which would promote infrastructure construction of the level of logistics-related industries, such as: transportation, warehousing, distribution, postal and telecommunications industries [36]; Rodrigo Rezende Amaral (2015) confirmed the urban logistic development, traffic flows and investments in urban infrastructure construction had a great correlation [37]; Xiaowei Lin, Jianjun Li(2013) divided the logistics development system into five subsystems: the regional logistics functions system, the regional logistics network system, regional logistics demand system, regional economic system, auxiliary system. The subsystem of regional logistics functions mainly covered the indicators of logistics industry output. The construction volume of traffic and information were included in regional logistics network subsystem, The regional economic system included regional economic level indicator, while the regional auxiliary subsystem included funds, personnel, technology, policy and other indicators [38]; Liu He, Wang Jian (2014) chose the indexes of socio-economic development, logistics and market demand conditions, infrastructure status to research the logistics network system [39]. Ahmed Alshamsi, Ali Diabat (2015) designed the logistics network, involving the transportation, the initial investment of factors, from the aspects of logistics sector entities and government policy to illustrate[40]; Panos Kouvelis (2002) studied the factors impacted the regional logistics network included infrastructure financing, transportation planning, government subsidies in corporate tax law and other global utility production and distribution network [41].

Based on the above index system, the power systems of regional logistics industry networking involved four subsystems: the logistics industrial benefits subsystem, logistics industrial scale subsystem, logistics demands subsystem and logistics network resources subsystem. The indicators were shown in Table 2.

Table 2. Indicators on Regional Logistics Industry Networking

\begin{tabular}{|c|c|}
\hline Level indicators & Secondary indicators \\
\hline \multirow{6}{*}{$\begin{array}{l}\text { Logistics Industrial } \\
\text { Scales (X1) }\end{array}$} & Quantity of Wholesale corporate Enterprises C1 \\
\hline & Quantity of Retailing EnterprisesC2 \\
\hline & Quantity of Express Outlets C3 \\
\hline & The Number of Employment wholesale tradeC4 \\
\hline & The number of retail employeesC5 \\
\hline & $\begin{array}{l}\text { The number of loading, unloading and other transport services } \\
\text { employmentC6 }\end{array}$ \\
\hline \multirow{4}{*}{$\begin{array}{l}\text { Logistics Industrial } \\
\text { Benefits(X2) }\end{array}$} & Total import and export(One thousand US dollars)C7 \\
\hline & $\begin{array}{l}\text { Added value in Transportation, Storage and Postal industries (\$ } \\
\text { billion)C8 }\end{array}$ \\
\hline & The total sales of retail goods (million)C9 \\
\hline & Total sales of Wholesale trade (million) C10 \\
\hline \multirow{3}{*}{ Logistics Demands(X3) } & Sales index on RetailC11 \\
\hline & CPI C12 \\
\hline & Growth Index on Postal Business Volume C13 \\
\hline \multirow{4}{*}{$\begin{array}{l}\text { Logistics Network } \\
\text { Resources (X4) }\end{array}$} & Highway Mileage (ten thousand kilometers)C14 \\
\hline & Railway Mileage (ten thousand kilometers)C15 \\
\hline & The total Length of railway postal routes ( kilometers)C16 \\
\hline & The total length of postal routes ( kilometers) C17 \\
\hline
\end{tabular}


Total fixed asset investments in Information transmission, computer services and software industry( $\$$ billion)C18

Total fixed asset investments in Transportation, storage and postal services industry ( $\$$ billion $) \mathrm{C} 19$

Analyzed of the indicators of four subsystems of networking impact mechanism,

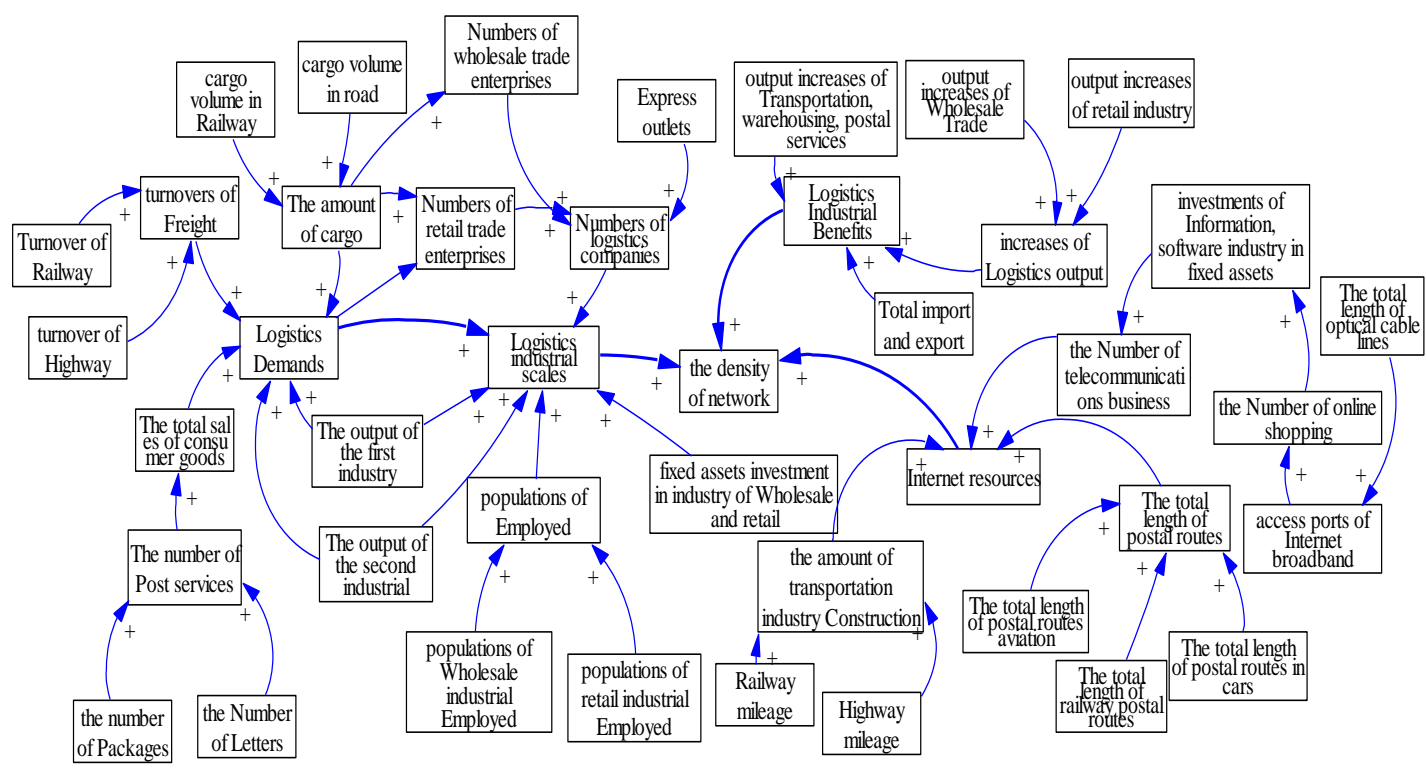

established the networking system of causality in Figure 1.

\section{Figure 1. Figure of Causality of Networking System}

There were four main feedback loops. Loop 1 showed elements of the logistics needs of logistics industry collaboration traction; Loop 2 represented Logistics industry itself spontaneously generate economies of scale and industrial expansion in the form of industrial integration; Loop 3 represented industrial efficiency driving the network of logistics industries construction; Loop 4 represented network resources in regional logistics infrastructure driving industry networking.

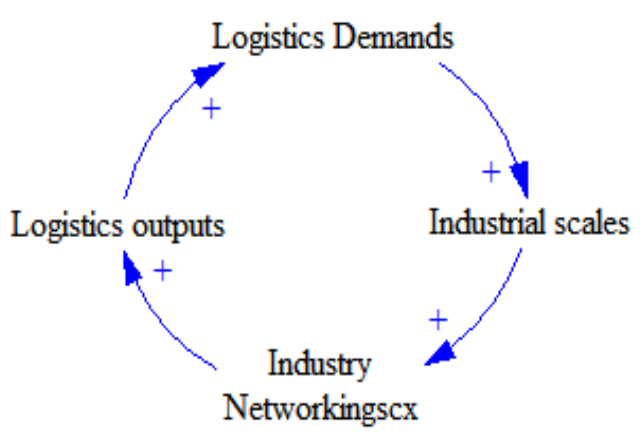

Loop1

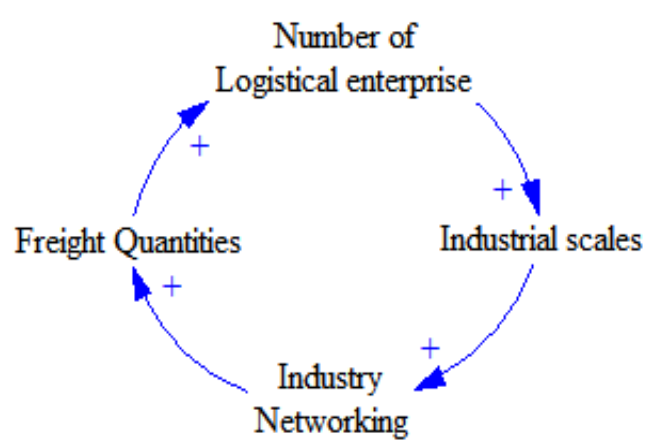

Loop2 


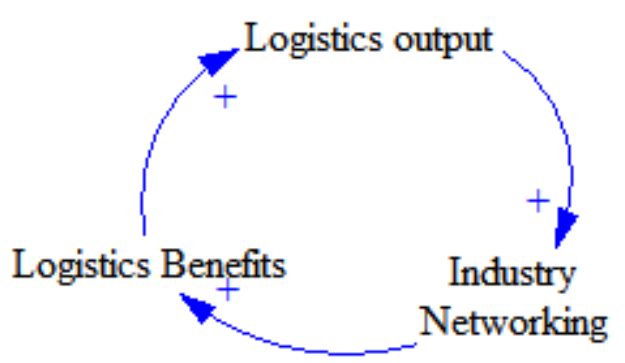

Loop 3

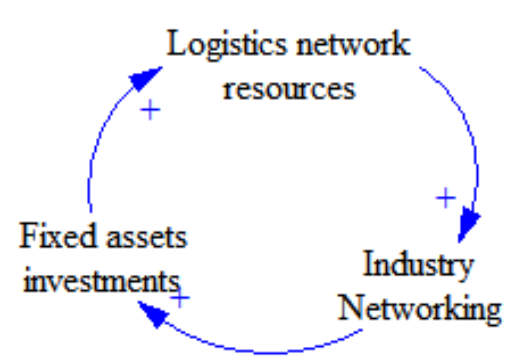

Loop 4

\subsection{The Dynamics Model of Networking of Logistics Industry in Region of Jing-Jin- $\mathrm{Ji}$}

(1)The description of dynamics Model on logistics industry networking in Jing-Jin-Ji Based on the system of causal feedback diagram, established the flow diagram which reflected the dynamics relationship of regional logistics system, covering the four subsystems in Figure 2.From four dimensions of logistics system, established the system flow chart. Evoluting in four processes: factors of logistics demand driving the logistics industry collaboration, the growth of the regional people's consumption ability inevitably reflects the purchasing power in an area, and consumer goods logistics is required to transmit, leading to the market actual freight volume increasing which results in logistics industry continues increasing; Logistics industry scale and spontaneously produce industrial expansion in the form of industrial convergence, the number of logistics enterprises, the competition in the industry enhanced, inevitably induce effective fusion to form the industry advantage, cash as polymerization industry scale, industry efficiency is increased, the regional economic output increase too.In turn, the development of economic level will cause the ascent of the logistics freight volume; Industry benefits driven industry network integration, the logistics industry and subnetted development makes unit logistics flow than traditional industry benefits to ascend, enterprise benefit maximization of the guide will spontaneously to melt net direction; Regional logistics network infrastructure and drive the industry integration, the state of transportation, information industry increase in the number of fixed investment, regional infrastructure level, provides a solid platform for the logistics industry networking, and promotes the logistics network deepen and deepen in a certain period of time,

(2) Dynamic equations on logistics industry networking in Jing-Jin-Ji

The level of networking in the logistics industry was affected by complicated indicators according to the dynamics system model, in which the industrial scales, industrial efficiency, logistics demands, regional logistics network resources subsystems were comntained. Table 3, represented indexes which influenced the level of networking in the logistics industry. 


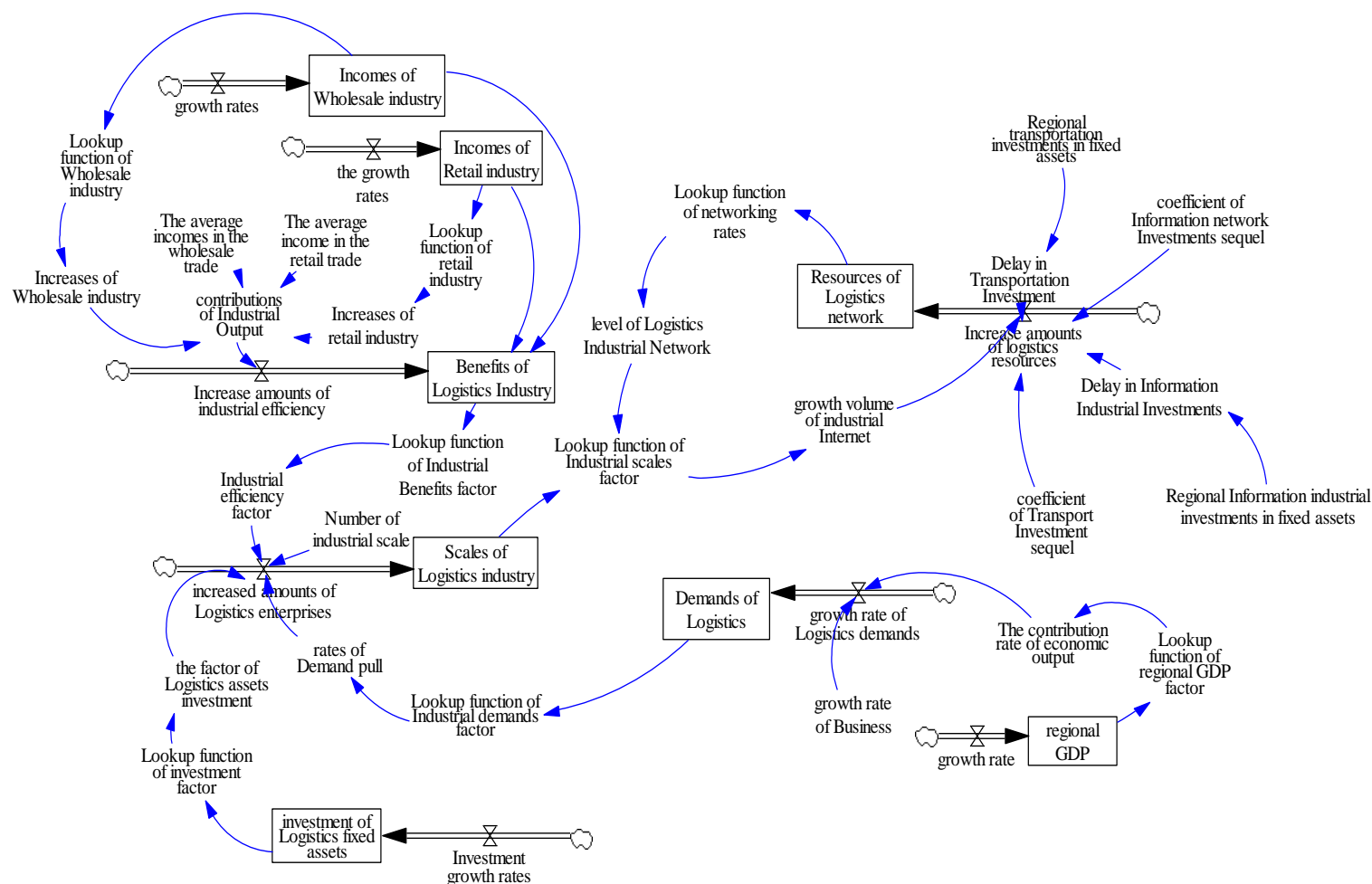

Figure 2.The Flow Diagram of Dynamics Model on Logistics Industry Networking in Jing-Jin-Ji

\section{Table 3. Indexes of System Dynamics Model on Logistics Industry Networking}

\begin{tabular}{|c|c|c|c|}
\hline Variable & Type & Definition & Unit \\
\hline Industrial efficiency & $\mathrm{L}$ & $\begin{array}{l}\text { Regional logistics industrial outputs (replaced by } \\
\text { transportation, post and telecommunications } \\
\text { industrial output) }\end{array}$ & $\begin{array}{l}\text { One hundred } \\
\text { million yuan }\end{array}$ \\
\hline Industrial scales & $\mathrm{L}$ & $\begin{array}{l}\text { The number of regional logistics industry } \\
\text { enterprises (replaced by numbers of } \\
\text { transportation, post and telecommunications } \\
\text { industry) }\end{array}$ & \\
\hline Logistics Demands & $\mathrm{L}$ & $\begin{array}{l}\text { total cargo transport demands in regional } \\
\text { Logistics System }\end{array}$ & $\begin{array}{l}\text { One hundred } \\
\text { million yuan }\end{array}$ \\
\hline $\begin{array}{l}\text { Regional networks } \\
\text { resources }\end{array}$ & $\mathrm{L}$ & $\begin{array}{l}\text { total length of networks in Regional transport } \\
\text { and information Posts }\end{array}$ & Kilometer \\
\hline $\begin{array}{l}\text { Sales of Wholesale } \\
\text { industry }\end{array}$ & $\mathrm{L}$ & Output of the Wholesale trade industry & $\begin{array}{l}\text { One hundred } \\
\text { million yuan }\end{array}$ \\
\hline $\begin{array}{l}\text { growth rate of Wholesale } \\
\text { trade }\end{array}$ & $\mathrm{R}$ & $\begin{array}{l}\text { average growth rates of Wholesale industrial } \\
\text { output value }\end{array}$ & \\
\hline $\begin{array}{l}\text { Growth of Wholesale trade } \\
\text { sales }\end{array}$ & $\mathrm{R}$ & $\begin{array}{l}\text { Logistics industry growth rates calculated by } \\
\text { the table function }\end{array}$ & \\
\hline $\begin{array}{l}\text { Sales of Wholesale } \\
\text { industry }\end{array}$ & $\mathrm{C}$ & Mean output on Wholesale trade industry & $\begin{array}{l}\text { One hundred } \\
\text { million yuan }\end{array}$ \\
\hline Sales of Retail industry & $\mathrm{L}$ & Output of Retail industry & $\begin{array}{l}\text { One hundred } \\
\text { million yuan }\end{array}$ \\
\hline $\begin{array}{l}\text { growth rate of retail } \\
\text { industry }\end{array}$ & $\mathrm{R}$ & The average growth rate of the retail industry & \\
\hline
\end{tabular}




\begin{tabular}{|c|c|c|c|}
\hline Growth rate of Retail trade & A & $\begin{array}{l}\text { Logistics industry Growth rate calculated by } \\
\text { Table function }\end{array}$ & \\
\hline Sales of Retail industry & $\mathrm{C}$ & The mean value of the retail industry & $\begin{array}{l}\text { One hundred } \\
\text { million yuan }\end{array}$ \\
\hline $\begin{array}{l}\text { Increase amount of } \\
\text { industrial efficiency }\end{array}$ & A & $\begin{array}{l}\text { annual growth on Logistics and industrial } \\
\text { efficiency }\end{array}$ & $\begin{array}{l}\text { One hundred } \\
\text { million yuan }\end{array}$ \\
\hline $\begin{array}{l}\text { Fixed asset investments in } \\
\text { Logistics industry }\end{array}$ & $\mathrm{L}$ & $\begin{array}{l}\text { Total investments in regional logistics } \\
\text { industry(replaced by wholesale and retail trade) }\end{array}$ & $\begin{array}{l}\text { One hundred } \\
\text { million yuan }\end{array}$ \\
\hline $\begin{array}{l}\text { Growth rates on fixed } \\
\text { asset investment }\end{array}$ & $\mathrm{R}$ & Growth rate on Regional Logistics investment & \\
\hline $\begin{array}{l}\text { Contribution Rate on } \\
\text { Logistics Industry } \\
\text { Investment }\end{array}$ & A & $\begin{array}{l}\text { Contribution rate the Logistics industry } \\
\text { investments to the increase logistics enterprises } \\
\text { calculated by using table functions }\end{array}$ & \\
\hline $\begin{array}{l}\text { Increased amounts } \\
\text { Logistics enterprises }\end{array}$ & $\mathrm{R}$ & $\begin{array}{l}\text { The amount of annual growth of logistics } \\
\text { enterprises }\end{array}$ & \\
\hline Industrial basic scale & $\mathrm{C}$ & The initial number of Logistics Enterprises & \\
\hline Rates pulled by Demands & A & $\begin{array}{l}\text { Logistics enterprises growth rate influenced by } \\
\text { Logistics demands }\end{array}$ & \\
\hline Regional economic output & $\mathrm{L}$ & Regional GDP & $\begin{array}{l}\text { One hundred } \\
\text { million yuan }\end{array}$ \\
\hline Regional output growth & $\mathrm{C}$ & $\begin{array}{l}\text { Growth rate of Regional national economic } \\
\text { output }\end{array}$ & \\
\hline $\begin{array}{l}\text { Demands pulled by } \\
\text { Economic Growth }\end{array}$ & A & $\begin{array}{l}\text { Growth rate of Logistics demands pulled by } \\
\text { Regional national economic output, }\end{array}$ & \\
\hline $\begin{array}{l}\text { Growth rate of Logistics } \\
\text { business }\end{array}$ & $\mathrm{C}$ & $\begin{array}{l}\text { Growth rate of transport ,postal and } \\
\text { telecommunication services }\end{array}$ & \\
\hline $\begin{array}{l}\text { Growth rate of Internet } \\
\text { Industrial volume }\end{array}$ & A & Internet volume of logistics industry & \\
\hline $\begin{array}{l}\text { Effect coefficient of } \\
\text { Transportation network } \\
\text { investment }\end{array}$ & $\mathrm{C}$ & $\begin{array}{l}\text { Effect coefficient of transportation, warehousing } \\
\text { investment growth to Regional networks }\end{array}$ & \\
\hline $\begin{array}{l}\text { Investments of Regional } \\
\text { transportation, } \\
\text { transportation in fixed } \\
\text { assets }\end{array}$ & $\mathrm{C}$ & $\begin{array}{l}\text { The average investments of Regional } \\
\text { transportation, transportation in fixed assets }\end{array}$ & $\begin{array}{l}\text { One hundred } \\
\text { million yuan }\end{array}$ \\
\hline $\begin{array}{l}\text { Effect coefficient of } \\
\text { Information network } \\
\text { investment }\end{array}$ & $\mathrm{C}$ & $\begin{array}{l}\text { Effect coefficient of information transmission, } \\
\text { computer services and software industry } \\
\text { investment growth to Regional networks }\end{array}$ & \\
\hline $\begin{array}{l}\text { Investments of Information } \\
\text { transmission, computer } \\
\text { services and software } \\
\text { industry in fixed asset }\end{array}$ & $\mathrm{C}$ & $\begin{array}{l}\text { The average investments of Regional } \\
\text { information transmission, computer services and } \\
\text { software industry in fixed asset }\end{array}$ & $\begin{array}{l}\text { One hundred } \\
\text { million yuan }\end{array}$ \\
\hline $\begin{array}{l}\text { Delay on Transportation } \\
\text { Investments }\end{array}$ & A & Investment Delay on regional traffic, transport & \\
\hline $\begin{array}{l}\text { Delay of Information } \\
\text { Investment }\end{array}$ & A & $\begin{array}{l}\text { Investment Delay on regional information } \\
\text { transmission, computer services and software } \\
\text { industry }\end{array}$ & \\
\hline $\begin{array}{l}\text { Function on Logistics } \\
\text { industry networking }\end{array}$ & A & $\begin{array}{l}\text { Relations function between Regional logistics } \\
\text { industry networking and network resources }\end{array}$ & \\
\hline $\begin{array}{l}\text { Degree of logistics industry } \\
\text { Networking }\end{array}$ & A & Degree of logistics industry Networking & \\
\hline
\end{tabular}


Where in, $\mathrm{L}$ represented the state variable, $\mathrm{R}$ means rate variable, $\mathrm{A}$ was an auxiliary variables, $\mathrm{C}$ was a constant variable. A total of 33 variables are in the model, in which eight state variables, eight rate variables, nine auxiliary variables (including 8 table functions), eight constant variables.

The model simulated the time of 2005 to 2024 according to the National Bureau of Statistics data in Beijing, Tianjin and Hebei. Table 4, showed the initial values for the simulation.

Table 4. Initial Values of Level Variables of the System Model

\begin{tabular}{l|l|l}
\hline Index & Initial value & Unit \\
\hline Industrial efficiency & 1470.68 & One hundred million yuan \\
\hline Industrial scales & 7992 & piece \\
\hline Logistics Demands & 1867.8 & One hundred million yuan \\
\hline Logistics network resources & 483117.43 & Kilometer \\
\hline
\end{tabular}

(1) The values of wholesale trade sales and retail sales

The income of Wholesale trade and retail trade was the main revenue of logistics industry. The data of wholesale trade and retail sales were chosen as basic values in this simulation model. The mean of Regional wholesale trade and retail sales data were selected as fixed income in logistic industry.

(2) The growth rates of regional economic output and logistics business

Regional economic output was measured by regional gross domestic product. The growth rate of regional gross domestic product was constant variable. The value was 0.138331, which was calculated through collecting the data from 2005 to 2014 in Beijing, Tianjin and Hebei region. The result of calculating the average annual growth rate of Logistics services amount was 0.1807 , which was designed as a value of constant variable.

(3) The investments in regional traffic, transport industry and information transmission, computer services and software industry in fixed assets

The investment in regional traffic, transport industry and information transmission, computer services and software industry in fixed assets changed slightly, which was set to be constant variable when simulated the level of investment .The statistics data of 20052014 Regional traffic, transport investment in fixed assets, information transmission, computer services and software industry in fixed asset investment, showed the values were 813 million and 17.56 billion yuan.

(4) The coefficients of investment in transportation network and information network

The coefficient of investment in transportation network ,namely the amount of logistics networks increased per unit in investment, was $2.4 \mathrm{~km} /$ million, which was the average ratio of the amount of investment each year and the length of next year transportation network obtained from "data of Statistics Bureau". Similarly, the coefficient of investment in information network was $3 \mathrm{~km} /$ million.

(5) The delay of investment in transport and investment in information

Due to the construction of transportation and information was time-consuming, the investment had time delayed. Particularly investing in roads building, railways longer, which cannot be ignored. The delay time of investment in transportation, warehousing industry was set to 2 years, investment in the information industry was set 1 year in this model. 


\subsection{The Check of Dynamics Model of Networking of Logistics Industry in Region of Beijing, Tianjin and Hebei}

(1)Validation

The purpose of validation test on model was to guarantee the model appropriate and to monitor the parameters reasonable and the structure correct. The result of the validation text proved that the dynamics model of networking of logistics industry in region of Beijing, Tianjin and Hebei was valid and the system's internal mechanism was impartial, the definition of variable description was correct, the unit of parameters was correct and reasonable. So the test of validation had been fulfilled.

(2)Authenticity

To test whether the model run results abnormal and test the function of the model stable, compared the results simulated the degree of networking of logistics industry with the rate of networking of logistics industry. It has found that the results simulated in the model fluctuated in the reasonable range $(10 \%-10 \%)$. Consequently, authenticity was checked acceptably.

Table 5. Results of Comparing the Simulation \& Historical Data

\begin{tabular}{l|l|l|l}
\hline Year & Rate of Networking & $\begin{array}{l}\text { Degree of Networking } \\
\text { simulated }\end{array}$ & Deviation \\
\hline 2005 & 0.14 & 0.190259 & $5.026 \%$ \\
\hline 2006 & 0.2 & 0.191298 & $-0.870 \%$ \\
\hline 2007 & 0.22 & 0.192352 & $-2.765 \%$ \\
\hline 2008 & 0.25 & 0.25353 & $-0.353 \%$ \\
\hline 2009 & 0.29 & 0.295817 & $0.582 \%$ \\
\hline 2010 & 0.327 & 0.300896 & $-2.610 \%$ \\
\hline 2011 & 0.36 & 0.336946 & $-2.305 \%$ \\
\hline 2014 & 0.403 & 0.415952 & $1.295 \%$ \\
\hline Sensitivity & 0.45 & 0.427706 & $-2.229 \%$ \\
\hline
\end{tabular}

(3) Sensitivity

Changed the parameters and the structure in the model and compared the output results of model to observe its sensitivity. So there were two approaches to analyze the sensitivity: one of them was parameters analysis, the other was structural sensitivity analysis. Causality in the model of the system was so clear that the structure of the model undoubted. Parameter sensitivity analysis was to test whether the result of the runs sensitive when the parameters were converted within a reasonable range. The model parameters changed at an amount of $-3 \%-3 \%$ to validate the level of networking in regional logistics industry, It has found that the degree of networking were within reasonable limits. Abnormal changes did not occur because of changes in parameters. Therefore, the model was sensitive. 


\section{Results of Simulating the Dynamic Model of Networking in Logistics Industry on Jing-Jin-Ji Region}

\subsection{Results of Simulation on Subsystem of Logistics Industry Benefits on of Jing- Jin-Ji Region}

Figure 3, showed, logistics industry benefits tended to upward tendency overall from 2005 to 2024 on Beijing-Tianjin-Hebei region. However, the rate of increase would was expected to tend to zero after 2015. That was to say, logistics industry benefits would behave smoothing after 2015. Figure 3, depicted the trends of the logistics industry benefits between 2005 and 2024, which was produced by Vensim software.

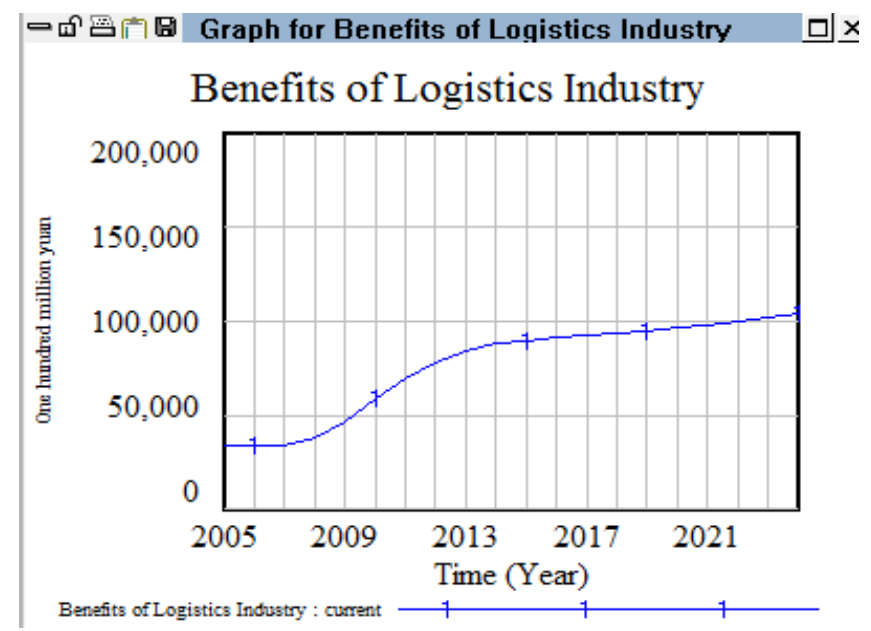

Figure 3. Figure of Logistics Industry Benefits Simulated

\subsection{Results of Simulation on Subsystem of Logistics Industry Scales on Jing-Jin-Ji Region}

Figure 4, showed the simulated results of logistics industry scales on Jing-Jin-Ji region. The curve represented the trends of the number of logistics enterprises, from which revealed the number of logistics wave firstly. After 2014 there would be no significant increase in the number of logistics enterprises.

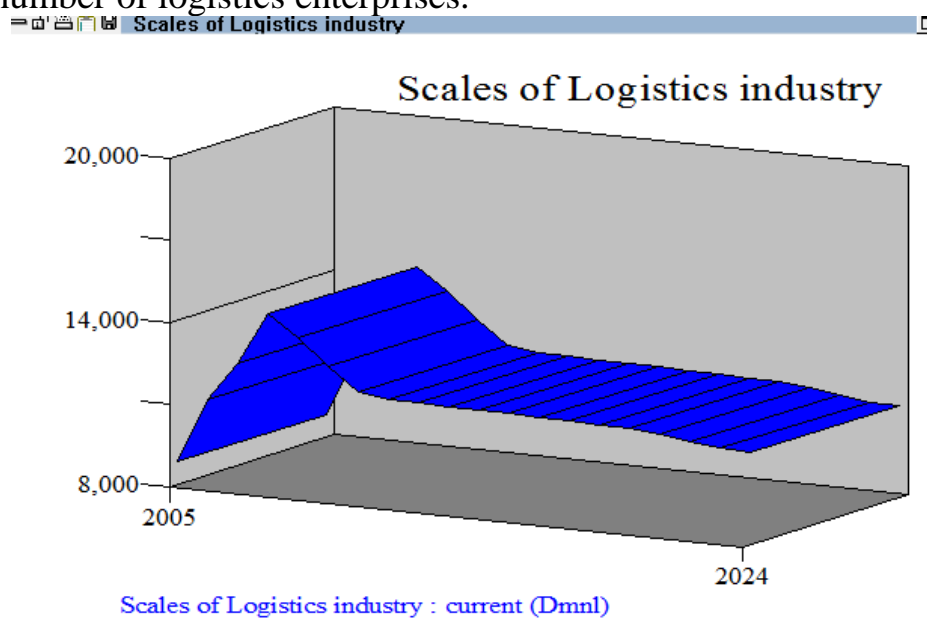

Figure 4. Figure of Logistics Industry Scales Simulated 


\subsection{Results of Simulation on Subsystem of Logistics Industry Demand on Jing-Jin-Ji Region}

Figure 5, showed an upward trend in the logistics demand curve formula. Logistics demands continued proliferation with economic growth on Beijing, Tianjin and Hebei logistics system, especially the growing rate of logistics demand after 2015 .
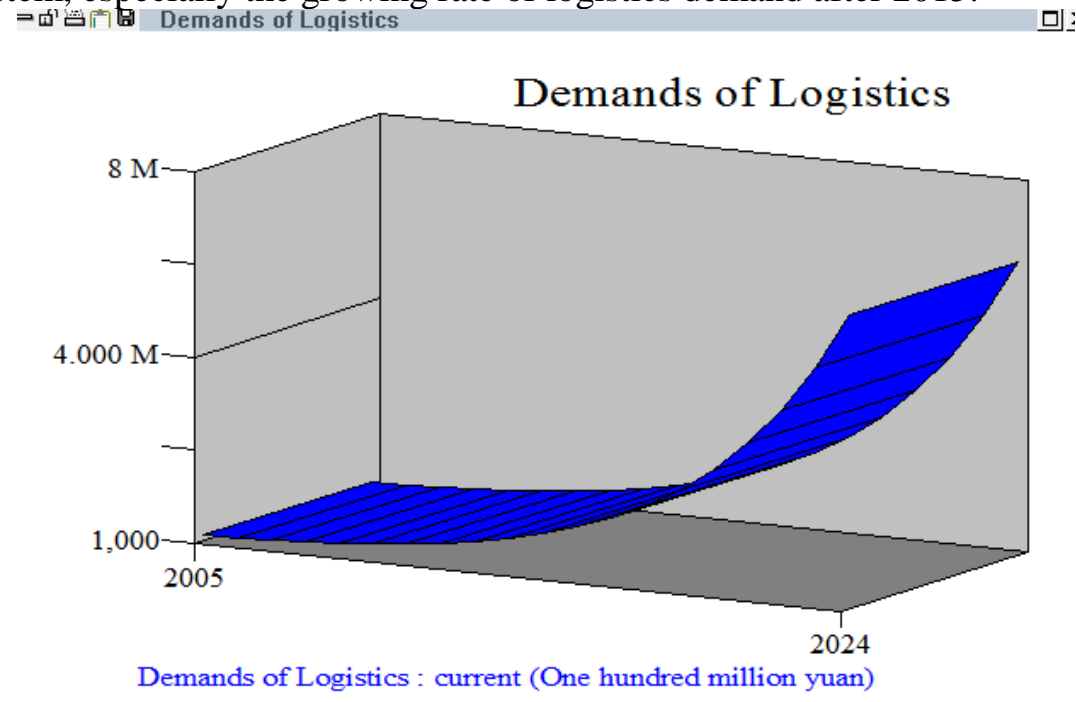

Figure 5. Figure of Logistics Industry Demands Simulated

\subsection{Results of Simulation on Subsystem of Logistics Network Resources on Jing-Jin-} Ji Region

Resources of logistics network included the transport network and information network resources, which were the result of investments in transportation, information industry from government on the basis of the existing network resources. Figure 6, showed the logistics network resources changing trend from 2005 to 2024, an overall linear growth simulated.

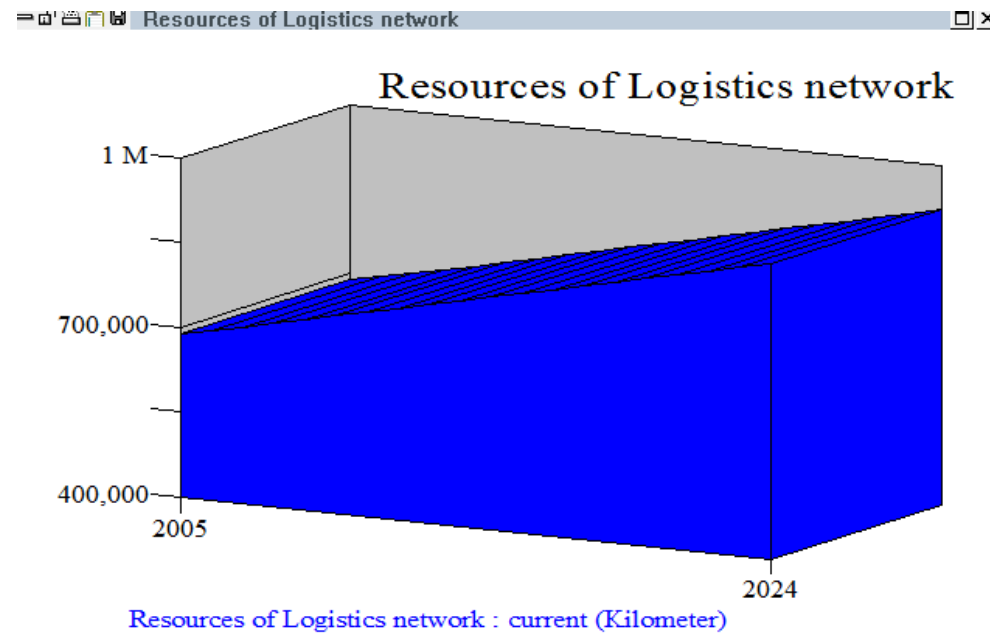

Figure 6. Figure of Logistics Network Resources Simulated 


\subsection{Results of Simulation on Level of Networking on Logistics Industry on Jing-Jin- Ji Region}

The level of networking of logistics industry was the consequent of being integrated by the four subsystems above. Figure 7, clarified the level of networking of logistics industry in Beijing, Tianjin and Hebei region. Distinctly, it was the peak of networking of logistics industry from 2010 to 2017, after which there was steady state continuously. As we all know, the rapid development of e-commerce had brought opportunities to many industries, which had been confirmed in logistics industry through the trend of changing from 2010 to 2015. And there would be another increases from 2015 to 2017. After that, it would maintain this level continuously.

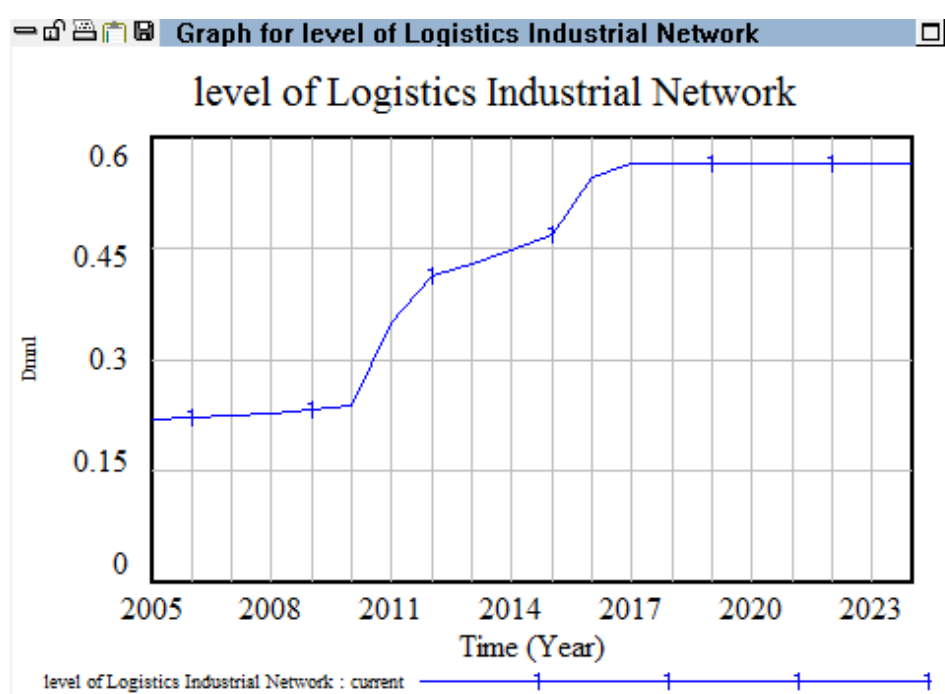

Figure 7. Figure of Level of Networking on Logistics Industry Simulated

\section{Dynamics Effects of Networking of Logistics Industry on Jing-Jin-Ji Region}

In the dynamics model of Networking of logistics industry on Jing-Jin-Ji region, there were two control variables, including wholesale trade sales and retail sales, affected the subsystem of logistics industry benefits. The factor which affected the subsystem of logistics industry scales was investment in logistics industry. what influenced the logistics demands were the variables of regional economic output growth rate and the growth rate of the logistics business. And the network resources were affected by the factors of investment in regional fixed assets of traffic, transport industry and investment in total fixed asset of information transmission, computer services and software industry. All of the variables above influenced the level of networking of logistics industry. But the extent of the influence was different. Observing the changes of the level of networking on logistics industry by the means of controlling variables of the four subsystems individually to determine the effect. When the variables increased $50 \%$, there was a significant result to distinguish of the effects.Figure 8, showed the effect of the four subsystems.The logistics benefits and logistics scales impacted more on networking of logistics industry in Beijing,Tianjin and Hebei.But it was not obvious that the effect of network resources, logistics demands on networking of logistics industry in Beijing,Tianjin and Hebei region. 


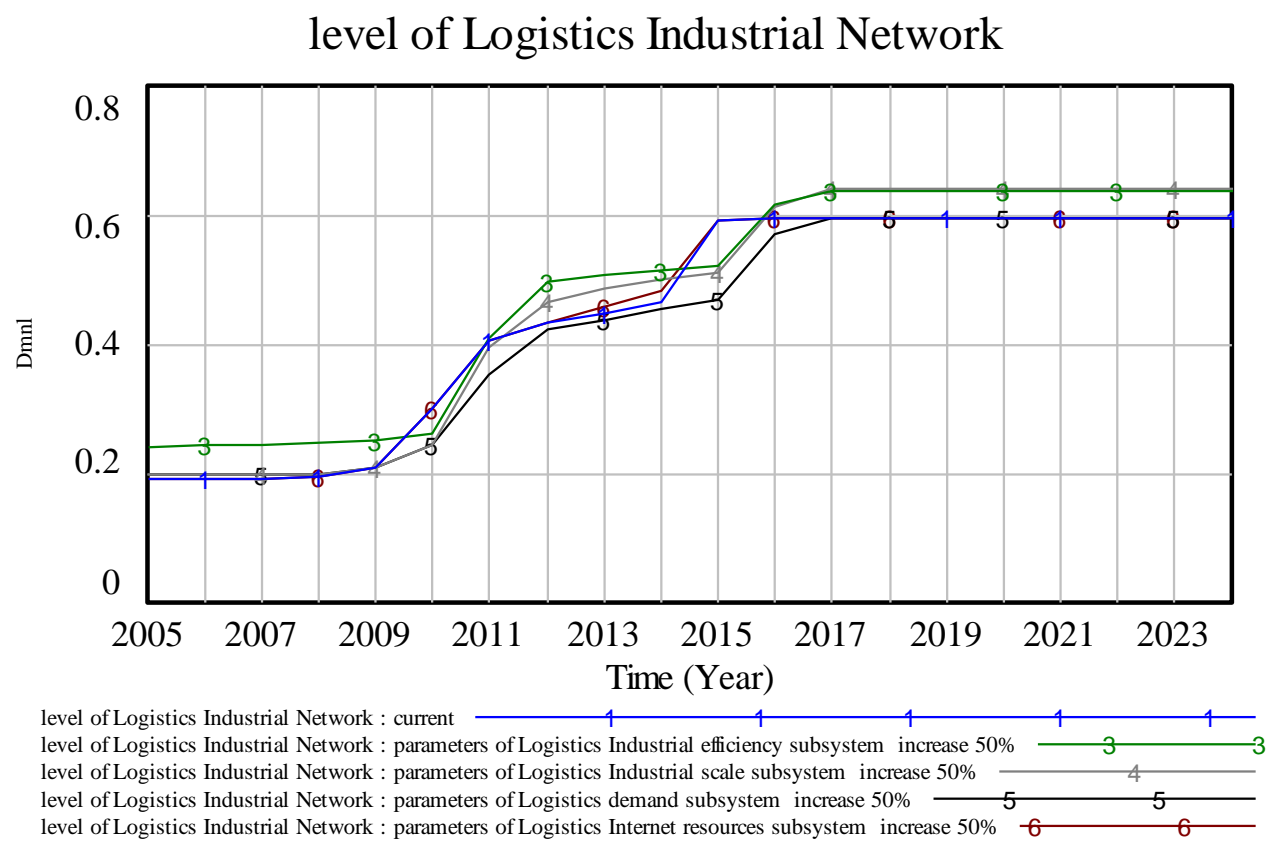

Figure 8. The Figure of the Effect of Networking on Logistics Industry

\section{Conclusion}

In this paper, based on the upshot of the research on logistics industry networking in the area of Jing-Jin-Ji, modeled and analyzed the system of logistics industry networked after reviewing literatures and refining the indexes about the logistics industry. A dynamics model was built to simulate the trend of logistics system development with the data of a decade from 2005 to 2014 in Jing-Jin-Ji region. The level of networking of the logistics industry was affected by four subsystems, whose trends had been simulated. Subsequently, observed the effect of the four subsystems by changing the parameters of each subsystem singly. The results showed that the efficiency of logistics benefit and logistics scales impacted obviously on the level of networking on logistics industry. While logistics demands and investments growth on the logistics network resources from government impacted slightly on the level of networking on logistics industry. It can be seen that the main drivers of networking of logistics industry on the region of Jing-Jin-Ji were logistics industry benefits and the logistics industry scales, which were the force prompted by enterprises who acted as the leader in the process of networking. However, the government's control to the networking of logistics industry was not perfect in JingJin-Ji .There was a vast space to exert the function of government to speed up the process of networking further.At last,the model established in certain economic and market environment, only apply to the Jing-Jin-Ji, no broad applicability.

\section{Acknowledgements}

This research was funded by the Humanities and social sciences key research base of scientific research Program "Under the joint development of Beijing, Tianjin and Hebei Province background traditional logistics industry networking mechanisms and Research Network of Development Path" in Universities in Hebei Province .This research is also supported by Science and technology research and development program of Hebei province soft science project (16455303D) "Innovative Development of Traditional Tourism in Hebei Province in the Context of Internet + ". 


\section{References}

[1] R. H. Ballou, "Logistics network design: Modeling and informational considerations", International Journal of Logistics Management, vol. 2, no. 6, (1995).

[2] H. Gleissner and J. C. Femerling, "Logistics Network Planning", Springer International Publishing Switzerland, no. 6, (2013).

[3] Sundar and D. Krishna, "Integrated virtual logistics network for quick responses", Traffic and Transportation Studies Proceedings of ICTTS , no. 2, (2002).

[4] T. Moriy and Nishikimi, "EconomicTransPort Densityandindustrial Agglomeration", Regional Science \& Urban Economics, no. 32, (2002).

[5] Ezzeddine Fatnassi and Jouhaina Chaouachi, Walid Klibi.Planning and operating a shared goods and passengers on-demand rapid transit system for sustainable city-logistics.Transportation Research Part B ,no. 81, (2015).

[6] A. Baykasoglu and K. Subulan, "Ananalysis of fully fuzzy linear programming with fuzzy decision variable sthrough logistics network design problem", Knowledge-Based Systems, no. 90, (2015).

[7] H. Feng, Y. Xin, D. Can and S. Xiao, "Nodes selection of regional logistics network based on hubandspoke theory. Computer Integrated Manufacturing Systems, vol. 6, no. 18, (2012).

[8] A. Bruzzone and P. Fadda, G. Fancello, M. Massei, E. Bocca, A. Tremori, F. Tarone and D. Errico, "Logistics node simulator as an enabler for supply chain development: innovative portainer simulator as the assessment tool for human factors in port cranes", Simulation: Transactions of the Society for Modeling and Simulation International, no. 87, (2011) .

[9] J. Tang and F. Yung and W. H. Andrew, "Heuristics-based integrated decisions for logistics network systems", Journal of Manufacturing Systems, no. 23, (2004).

[10] P.Schönsleben, "With agility and adequate partnership strategies towards effective logistics network", Computers in Industry, no. 42, (2000).

[11] W. Wang and X. J. Feng, "Research on continuous logistics node layout optimization based on weighted Voronoi diagram", Journal of Wuhan UniVersity of Technology (Transportation Science \& Engineering), vol. 6, no. 35, (2012).

[12] J. Cao, "Logistics network nodes planning and development strategy in Henan province", Proceedings of the 2010 International Conference on E-Product EService and E-Entertainment, (2010), Henan,China.

[13] M. Florio and S. colautti, "A Logistic Growth Theory of Public Expenditures: A study of Five Countries Over 100 Years", public Choice, no. 7, (2012).

[14] O. Melendez and M. Fernanda, "The logistics and transportation problems of Latin American integration efforts: The Andean Pact,a case of study", Knoxville: The University of Tennessee, (2002).

[15] T. Skjott-Larsen and U. Paulsson and S. Wandel, "Logistics in the oresund region after the bridge", European Journalof Operational Research, no. 1, (2003).

[16] Tuzkaya and Gulfem, "A methodology for the strategic design of reverse logistics networks and its application in the Turkish white goods industry", International Journal of Production Research, no. 9, (2011).

[17] A. P. Trunic, "Finding a Place for Logistics Management", Scm.ncsu.edu, no.1, (2003) .

[18] A. D. Marco and R. Carlo, "System Dynamics Simulation:an Applicationto Regional Logistics Polycy Making”, International Journal of Computers,vol. 4, no.1, (2007).

[19] Z. Chenguang and Z. Meiqing, "Research of Regional Logistics Intelligent Information Platform Based on Internetof Things.Informatics and Service Science, (2013).

[20] C. Woudsma, J. F. Jensen and P. Kanamglou, "Logistiesland use and theeity :Aspatial temporamodeling approach", TransportationResearch, no. 44, (2008).

[21] A. Smirnov and N. Shilov, "Service-Based Business Network Modelling:Application to Dynamic Logistics", International Federation for Information Processing, no.15, (2008).

[22] L. Xiaopeng, "An integrated modeling framework for design of logistics networkswith expedited shipment", Transportation Research Part E, no. 56, (2013).

[23] Y. Peng and H. Chen, "Post-seismic supply chain risk management: A system dynamics disruption analysis approach for inventory and logistics planning", Computers \&OperationsResearch, no. 42, (2014).

[24] G. Shouping and Z. Qiang, "System dynamics model of regionallogistics and it algorithm analysis", Journal of South China University of Technology: Natural Science, no.10, (2003).

[25] H. Feng and Z. Dawei, "Research on the evolution mechanism of industry cluster and regional logistics network system", Logistics Engineering and Management, no. 30, (2010).

[26] Zhaolei and W. Qunqi and Z. Yaqi, "Evolution mechanism of regional logistic system based on dissipation structure theory", Journal of Chang'an University: Social Science Edition, no. 4, (2010).

[27] D. Antonelli and B. Caroleo, "An integrated methodology for the analysis of collaboration in industry networks", Journal of Intelligent Manufacturing, no.10, (2011).

[28] Shuqin, "Research on Computer-based Creative Industries Development", International Conference on Medical Physics and Biomedical Engineering,Physics Procedia, no. 33, (2012).

[29] J. Xu and L. Jiang and S. Wang, "Construction of Pick-Up Points in China E-commerce Logistics", International Conference on Cybernetics, vol. 3, no. 16, (2014). 
[30] Z. L. Jiao, "Modes and Development Characteristics of China's Cross-border E-commerce Logistics", Springer-Verlag Berlin Heidelberg, no. 12, (2016).

[31] F. Karray and M. Alemzadeh and J. A. Saleh, "Human-Computer Interaction: Overview on state of the Art", Inter. J. Smart Sensing and Intelligent Systems, no. 12, (2008).

[32] J. Xu, L. Hong and Y.L. Li, "Designing of collection and delivery point for e-commerce logistics", Proceedings of international conference of information technology, computer engineering and management sciences, Beijing, China. (2011) November 3.

[33] R. Sarraj, E. Ballot and S. Pan, "Analogies between Internet network and logistics service networks: challenges involved in the interconnection",Intell Manuf, no. 25,(2014).

[34] D. Antonelli and B. Caroleo, "An integrated methodology for the analysis of collaboration in industry networks", Journal of Intelligent Manufacturing, no. 10, (2011).

[35] L. Zhao, "Study of Coordinated Development of Logistics Industry and Regional Economic Integration Based on Provincial Data", Proceedings of the 2nd International Conference on Green Communications and Networks, no. 1, (2012).

[36] S. Poncet, "Measuring Chinese domestic and international integration", China Econ Rev, vol. 14, no. 3, (2003).

[37] R. R. Amaral and E. H. Aghezzaf, "City Logistics and Traffic Management: Modelling the Inner and Outer Urban Transport Flows in a Two-Tiered System", Transportation Research Procedia, no. 6, (2015).

[38] L. Xiaowei and L. Jianjun, "Measurement and Evaluation on synergy level of the regional logistics", Chinese Circulation economy, no. 11, ( 2013).

[39] L. Holland and W. Jian, "The research of building regional logistics network and empirical at the theory of hub and spoke", Economic Geography, vol.2, no. 34, (2014).

[40] A. Alshamsi and A. Diabat, "A reverse logistics network design", Journal of Manufacturing Systems , no. 37, (2015).

[41] D. Sundar and Krishna, "Integrated virtual logistics network for quick responses", Traffic and Transportation Studies Proceedings of ICTTS, no. 2, (2002).
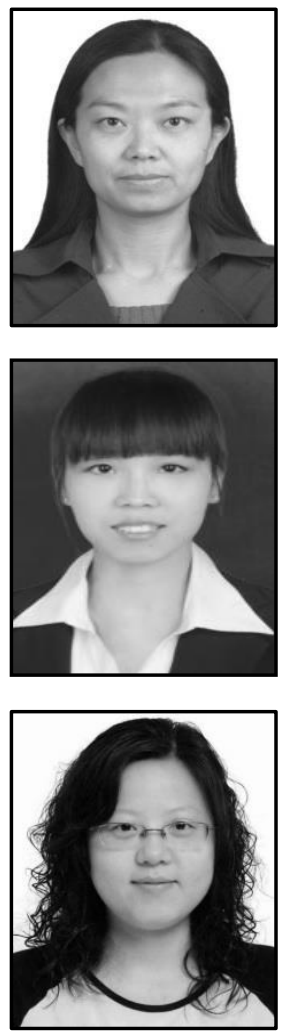

\section{Authors}

Bo Shu, received Doctor Degree in Management and currently is a professor of Yanshan University in China. Her current research area are about strategy management, Supply Chain Management, Complex network in industry, etc.

Shan Lu, She is admitted by Yanshan University in 2014 and majors in Logistics Engineering. The main research area are about regional logistics and complex networks in industry.

Haiju Hu, she received her Ph.D. degree in decision science and managerial economics from the Chinese University of Hong Kong, Hong Kong. She is currently a lecture in the Economics and Management School at Yanshan University, China. Her research area are supply chain management, quality management and complex network. 
International Journal of $u-$ and e- Service, Science and Technology Vol. 9, No. 11 (2016) 